\title{
Cross-strait Financial Distress Pre-warning Models that Include Corporate Governance: Reestimating Ohlson's Models
}

\author{
Kuang-hua $\mathrm{Hu}^{1, *}$, Da-bai Shen², Jin-Long Huang ${ }^{3}$ \\ ${ }^{1}$ Department of Accounting, Nanfang College of Sun Yat-Sen University, China \\ ${ }^{2}$ Department of Accounting, Soochow University, Taiwan \\ ${ }^{3}$ Cosmos Bank, Taiwan
}

Copyright (C) 2015 Horizon Research Publishing All rights reserved.

\begin{abstract}
This paper uses listed cross-strait (China and Taiwan) companies during 2006-2010 to demonstrate the application of a logistic regression to establish financial distress pre-warning models. The bankruptcy indicators are selected by three stages, namely a Wilcoxon test, a ridge regression, and a stepwise refinement. We attempt to determine whether predictors can be obtained by incorporating corporate governance variables that could increase failure predictability. Both non-outstanding state shares and share-holding of placement institutions are flagged positively and significantly in the pre-warning model in China; this finding conforms with the "conflicts of interest hypothesis." The share-holding by foreign institutions negatively impacts the financial crisis, a finding that is in keeping with the "efficient supervisions hypothesis." The negative and significant relation associated with the director share-holding and financial crisis in Taiwan is in accordance with the "convergence of interest hypothesis." Cross-shareholding has a positive effect on a firm's failure in Taiwan. The results also demonstrate that the integrated model has the best capacity to identify pre-warning models among all models. For the models of estimation, Taiwan's model is slightly superior to China's model.
\end{abstract}

Keywords Pre-warning Model, Corporate Governance, Logit Model, Financial Distress

JEL Classification: G32; G33; G34

\section{Introduction}

As the recent financial crisis has once again underlined, the establishment of a pre-warning model of enterprise financial distress has been an essential task for decision-makers. The prediction of bankruptcy $[13,55]$ has been an extensively research area since late 1960s [1], and such efforts have focused on firms' financial problems.
However, the development and refinement of corporate governance norms have followed the serial collapses of a number of financial companies. Established risk management systems have failed in many cases due to corporate governance procedures rather than inadequate computer models.

First released in 1999 and last revised in 2004, the Organization for Economic Cooperation and Development (OECD) principles of Corporate Governance have been subject to a further review by committee in 2014 [39]. To ensure the continuing high quality, relevance, and usefulness of the OECD principles, policy makers should take recent developments in capital markets into account to ensure they have a sound benchmark for establishing an effective corporate governance framework. To confirm that banks have an appropriate level of capital when implementing financial innovation that may produce enormous risk, the Basel Committee on Banking Supervision revised the Basel Capital Accords (Basel I, Basel II, Basel III), requesting enterprises to establish a suitable risk management system to decrease the impact of any financial crisis. The Asian Corporate Governance Association also demonstrated that appropriate corporate governance will assist enterprises by ensuring good operations. Erkens, Hung, and Matos [20] indicated that governance mechanisms are indeed available to firms. Consequently, the poorer a firm's corporate governance, the higher is its probability of going bankruptcy [22], as a corporate governance system is a key factor in determining if an enterprise will experience a crisis. Remarkably, a financial crisis does not only impact financial industries; hence, effective corporate governance systems are essential across enterprises in all industries. The pioneering work of Ohlson [40] used a logit regression to construct a financial pre-warning model, which was followed by many other models, such as Muller, Steyn-Bruwer, and Hamman [37], Tseng and Hu [51], and Huang, Chang, and Liu [29]. Most scholars adopt paired-samples and only consider financial factors to establish their model; however, full samples are better able to 
boost a model's precision.

Due to increasingly frequent cross-strait (between China and Taiwan) financial transactions and special relations, there still exists a much greater difference in the countries, such as corporate culture and nature. For example, most state-owned enterprises listed in China face stronger central control, which runs counter to the long-term stable enterprise development [27]. Previous studies on bankruptcy prediction have concentrated on financial factors in building models or making comparisons. In this paper, we expend the application of Ohlson's model by reestimating the model on data from Chinese and Taiwanese publicly listed companies. The logistic regression model has a better overall fit and a higher percentage of failure prediction than the discriminant model [53]. The issue for this article is not only the role of corporate governance in this situation, which has been well documented elsewhere [7], but also to understand the cross-strait market situation that faced financial crisis and in which their business models and corporate governance arrangements had to use a default pre-warning model.

The remainder of this paper is organized as follows. In Section II, the existing literature on corporate governance development and measurement techniques are discussed. In Section III, the logit model and examination of validity are described. In Section IV, data and the choice of variables are demonstrated. In Section V, the cross-strait model is constructed and analyzed. Based on the findings, some conclusions and remarks are presented in Section VI.

\section{Literature Review}

The academc literature on the prediction of corporate failure has been focused on using accounting data. For example, Duan, Sun, and Wang [18] employed a forward intensity construction to estimate a firm's default probability for different periods and suggested that factors such as a firm's leverage [19], liquidity, profitability, and volatility [19] are critical for making default predictions. Shumway [48] and Beaver, McNichols, and Rhie [5] indicated that a firm's earnings were also an important determinant of default prediction. As the financial environment is ever-changing and enterprises encounter increasing uncertainty, methods to predict corporate defaults should be modified to reflect these changes.

\subsection{Corporate Governance}

The concept of corporate governance has been emerging since the early 1970 s, but has become especially prominent following the Asian financial crises in 1997. The accounting scandals of Enron/Worldcom have also pointed to issues with respect to internal control management and related auditor requirements. Since the mid-2008, the crisis in the U.S. subprime market had a significant impact on financial institutions and non-financial enterprises in many countries, leading to a number of collapses in the third quarter of 2008. In 2004, the Committee of Sponsoring Organizations of the Treadway Commission (COSO) proposed an enterprise risk management-integrated framework to help managers cope with uncertainty and other related risks and opportunities, designed to enhance an enterprise's ability to create value.

Enterprises in the U.S., the U.K., and Canada have taken steps to face possible risks and to develop a multidirectional corporate governance strategy, as well as establish strict corporate governance standards [33]. Bayrakdaroglu, Erosy, and Citak [4] analyzed the relation between the principles of corporate governance (e.g., size of the board of directors; ownership concentration) and firm performance [9]. Although corporate governance factors can help alleviate an enterprise crisis, as discussed by Jensen and Meckling [30], Daily and Dalton [17], and Chen, Chi, and Kuo [11], they do not work flawlessly in practice.

The composition of the board of directors has an influence on corporate performance [54]. Jesen and Meckling [30] and Poletti-Hughes and Ozkan [42] indicated that the separation of ownership and control, as well as the proportion of shares owned by directors and supervisors influence corporate performance. However, with a much bigger separation of ownership and control, controlling shareholders tend to execute a poor operations model, which may increase the probability of bankruptcy [16]. Chiou, Hsiung, and Kao [15] suggested a negative relation between the proportion of collateralized shares and corporate operating performance. In cases where directors and supervisors use shares as collateral to obtain personal funds, a fall in the stock price will leave them facing diminishing firm value and rising business distress. Patton and Baker [41] showed that having a chairman of the board as a general manager has a positive effect on the probability of a firm experiencing a financial crisis. Ching, Firth, and Rui [14] analyzed how family-controlled shareholders in China dominate corporate affairs, which leads to a lack of independence between directors and supervisors. Joh and Jung [31] showed that if a firm's board of directors is independent, the firm is less likely to expropriate the interests of equity investors. Using Chinese fraud listed firms as example, Chen et al. [12] found that firms having a higher ratio of non-decision makers on the board exhibited lower fraud, and the relation between the number of board meetings and the fraud is positive.

\subsection{Measurement Techniques}

Statistical methods such as regression, logistic models, and factor analysis, as well as data mining techniques including neural networks, fuzzy logic, and genetic algorithms have been used in constructing bankruptcy prediction models. Despite the variety of models available, Altman's Z score model [1,2] and Ohlson's model [40] are the most widely used bankruptcy prediction models [8]. After Altman's Z score model was devised, many relevant studies have been conducted, including Selkälä, Ronkainen, 
and Alassarela [46], Altman [3], and Rim and Roy [43]. Numerous researches have also been performed on the Ohlson model, e.g., Boritz, Kennedy, and Sun [8], Muller, Steyn-Bruwer, and Hamman [37], Hamdi and Mestiri [24], and Trabelsi et al. [50]. Zmijewski [56] provided financial distress models using simple probit and bivariate probit assessment. Numerous studies have also shown that artificial intelligence such as neural networks can be alternative methods for bankruptcy prediction $[32,47]$.

In econometrics, logistic regression types are often used to evaluate financial data. Ohlson [40] selected nine independent variables of industrial firms, exclusion utilities, transportation companies, and financial services companies from the period 1970-1976 that had been traded on a U.S. stock exchange for at least three years. Three models used a logistic function to predict failures within 1 year, within 2 years, or in 1 or 2 years, respectively. The predictive powers of three models have high lever, especially for size, current liabilities divided by current assets, net income divided by total assets, and funds provided by operations divided by total liabilities. Nikolaos and Iordanis [38] showed that simple logistic function and logistic model trees performed optimally among logistic regressions. This methodology provided a better approximation to the continuum of alternative financial judgment and actions in reality [34].

\section{Model and Estimation Method}

A logistic analysis in this paper was used to build pre-warning models. The following sections apply a receiver operating characteristic (ROC) curve $[23,25]$ and a Kolmogorov-Smirnov (KS) test $[45,49]$ to evaluate the goodness-of-fit.

\subsection{Logit Model}

A binary logit model was implemented by Berkson [6] and mostly applied to binary response models, such as logit and probit regressions by Ohlson and Zmijewski. Ohlson [40] applied logistic functions to bankruptcy prediction by the binary sample space of bankruptcy versus non-bankruptcy, in a model that can simultaneously deal with continuous data and categorical data. The acquired probability during 0 to 1 by this statistic method does not need the assumption of normal distribution. If we suppose that $\mathrm{Y}=1$ are failed companies and $\mathrm{Y}=0$ are non-failed companies, this model can be expressed as

$$
Z_{i}=\alpha_{i}+\sum_{k} \beta_{k, i} X_{k, i}+\sum_{j} \gamma_{k, i} Y_{j, i}+\varepsilon_{i}
$$

where $\alpha_{i}$ is intercept of the $i$ th company, $\beta_{k, i}$ is the estimated parameter of the $k$ th financial variable for the $i$ th company, $X_{k, i}$ is the $k$ th financial variable of the $i$ th company, $\gamma_{k, i}$ is the estimated parameter of the $k$ th corporate governance variable for the $i$ th company, and $Y_{j, i}$ is the $j$ th corporate governance variable of the $i$ th company. A probability $P_{i}$ is obtained by transposing eq. (1), which can be given as follows:

$$
\begin{gathered}
P_{i}^{1}=P(Y=1)=\frac{e^{z j}}{1+e^{z j}}=\frac{1}{1+\exp \left(-Z_{i}\right)}+\frac{\exp \left(Z_{i}\right)}{1+\exp \left(Z_{i}\right)} \\
P_{i}^{0}=P(Y=0)=1-P(Y=1)=1-P_{i}^{1},
\end{gathered}
$$

where $P_{i}$ denotes the probility of the $i$ th company in failed companies, and $1-P_{i}$ denotes the probility of the $i$ th non-failed company. Finally, the maximum likelihood estimation can be adopted to calculate the all parameters.

\subsection{Examination of Validity}

According to the Basel accord, the overall value of the goodness-of-fit test can be assessed through the use of ROC curve and KS test, specified as follows.

\subsubsection{ROC curve}

An ROC curve is formed by plotting the proportion of correct positives [26] among all true positives (known as the true positive rate; TPR) vs. the proportion of false positives out of the total of actual negatives (known as the false positive rate; FPR), at various threshold settings (Figure 1.). In this paper, credit scoring models were used to formulate the different curves, and the curve closer to the upper left corner indicates that it offers better bankruptcy predictions [57].

\subsubsection{KS Test}

The original concept of the KS test is that it determines the maximum difference between an empirical and hypothetical cumulative distribution [21]. This paper documents the KS test as the maximum difference between the cumulative distributions of a non-default and a default enterprise. However, a higher level of a KS test corresponds to a model having stronger discrimination capability between the two groups. Mays [36] showed that KS $<20$, $20<\mathrm{KS} \leq 40,40<\mathrm{KS} \leq 50,50<\mathrm{KS} \leq 60,60<\mathrm{KS} \leq 75$, and $\mathrm{KS}>75$ represented no, ordinary, good, very good, and best differentiation power, respectively. 


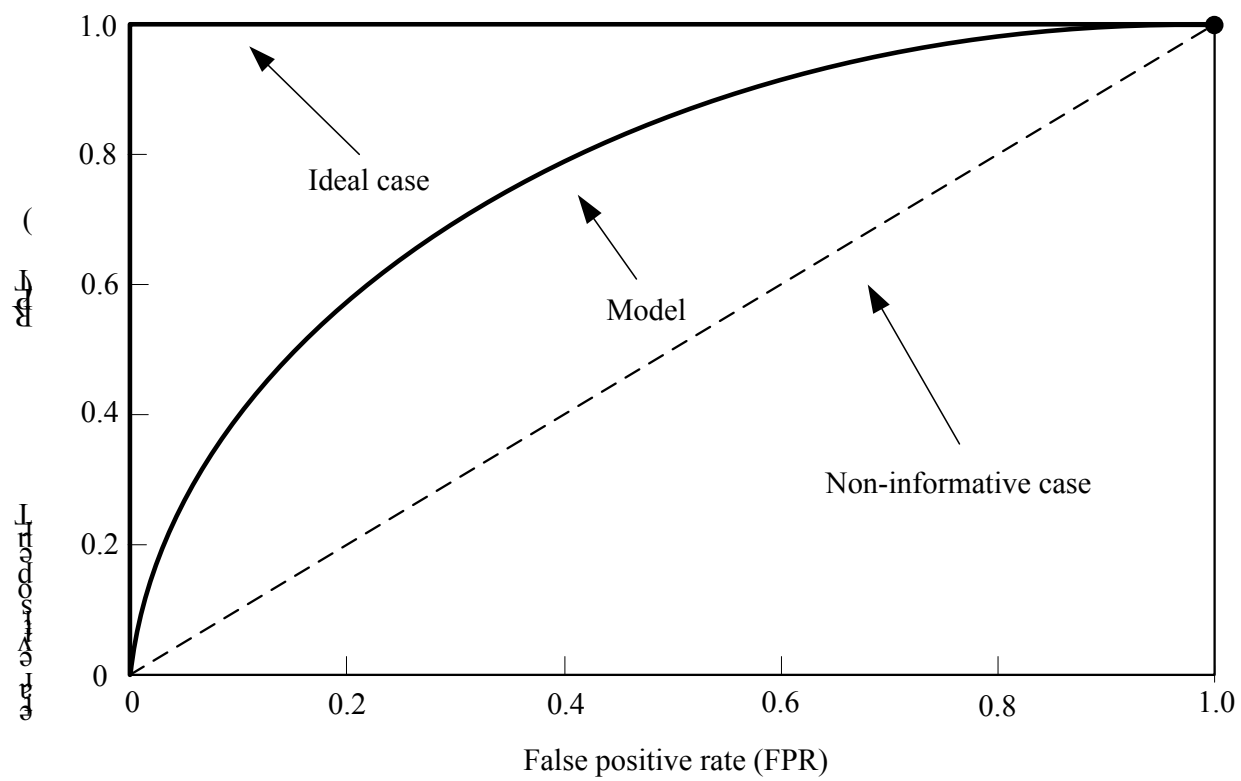

Figure 1. ROC curve

\section{Sample Selection and Sampling Procedure}

This section focuses on cross-strait corporate governance development and data collection. It also describes how to apply the proposed method to cross-strait current corporate governance to construct pre-warning models and examines the models' goodness-of-fit.

\subsection{Background Description}

China has been transitioning from a planned economy to a market economy. However, the Chinese economy is export-orientated, and therefore, depends heavily on international trade; this trait means it is significantly exposed to the impacts of a global financial crisis. In fact, in 2007, China experienced its first increase in bankruptcy cases since 2002. Until recently, a series of corporate scandals damaged the investors' confidence. To attract increased international investors and recover investor enthusiasm, China's government enacted corporate governance reform, which entailed the privatization of state-owned enterprises starting in the 1980s [10]. China's Securities Regulatory Commission declared that a plan to improve corporate governance had been given top priority since the YingGuangXia fraud, which was the biggest economic scandal in China in 2001 [35]. Given that the separation of regulatory and management roles is a very new concept in China, it takes a certain amount of time to ensure that a properly functioning regulatory system is capable of providing effective oversight.

Corporate Governance Reform was established by the Executive Yuan in Taiwan in January 2003. As part of these reforms, listed companies were requested to appoint independent directors to enhance board autonomy and strengthen their various functional committees [52]. In addition, the government has promulgated and implemented "Corporate Governance Best-Practice Principles for Taiwan Stock Exchange Corporation/GreTai Securities Market (TWSE/GTSM) Listed Companies," and "Ethical Corporate Management Best Practice Principles for TWSE/GTSM Listed Companies," among others, with the aim to help and guide listed companies in the establishment, implementation, and utilization of corporate governance systems. In response to rapid developments in corporate governance reforms in neighboring countries, the Financial Supervisory Commission (FSC) issued a 5-year "Corporate Governance Roadmap" in December 2013, aiming to accelerate the implementation of corporate governance among Taiwanese listed companies and assist the sound development of companies [52].

The relation between China and Taiwan is a special one; the cross-strait economic relationship has blossomed. According to Taiwan's Bureau of Foreign Trade, bilateral trade between China and Taiwan in 2013 reached $\$ 124.3$ billion, up from $\$ 10.4$ billion in 2000 . China is Taiwan's largest trading partner; in 2013, 26.77\% of Taiwan's exports were sold to China. Likewise, Taiwan ranks in the top ten of China's trading partners. Moreover, Taiwanese businesses have invested approximately $\$ 133$ billion in China between 1991 and 2013 based on data from the Investment Commission, Ministry of Economic Affairs of Taiwan. In the light of the special circumstances of cross-strait relations and financial trend, this issue warrants further investigation.

\subsection{Data}

The original data used in this study were collected by the Taiwan Economic Journal (TEJ) from 2006 to 2010, excluding financial services companies and construction companies. This study included a normal sample size of 
12622 enterprises and a crisis sample size of 774 enterprises for China, and a normal sample size of 4924 enterprises and a crisis sample size of 332 enterprises for Taiwan. The sample of Chinese enterprises focused on A-shares and B-shares for the Shanghai Stock Exchange and the Shenzhen Stock Exchange. Test samples from 2011 and 2012 are used to identify the prediction model's accuracy. According to the aforementioned studies and TEJ database, we select 19 items of financial data and 11 corporate governance variables (Table A1.) for China, and 21 items of financial data and 18 corporate governance variables (Table A2.) for Taiwan. The corporate governance variables, based on TEJ corporate governance framework and reform priority, draw six major categories as follows: (1) ownership structure and shares held by directors and supervisors; (2) equitable treatment of shareholders; (3) quality of financial reporting; (4) personnel turnover rate; (5) related party transactions; and (6) rights and responsibility of the board of directors. Given its integrity and the need to make a consistent comparison, we employed a definition and determination criteria for defaults based on the TEJ database in our cross-strait analysis.

Observations that are $+/-3$ standard deviations from the mean are treated as outliers and are eliminated. That left 6992 normal samples and 692 abnormal samples for China, and 2675 normal samples and 248 abnormal samples for Taiwan. Details are presented in Tables 1 and 2. The summary statistics show that China has the highest overall default rate and certified public accountant (CPA) opinion is second. Table 2 also indicates that defaults are higher than other crisis factors, namely, bounce/overdue/bailout in Taiwan. Similar to Shumway [48], we take unbalanced data into account as part of our logistic analysis, as financial statements focus on consolidated semi-annual reports and annual reports. If we were unable to locate consolidated reports, then reports of parent companies were substituted. Annual corporate financial reports are usually announced before the end of the following April, a schedule that naturally lends itself to an annual May 1 crisis point and the prediction of whether the firm will face a crisis within a year. If the default point occurred between $1 / 1$ and $4 / 30$, the financial statement of the T-2 year was used. If the default point occurred between $5 / 1$ and $12 / 31$, the financial statement of the $\mathrm{T}-1$ year was used.

\subsection{Mann-Whitney-Wilcoxon (Wilcoxon) Test and Ridge Regression}

The Wilcoxon test is used to extract important variables from pre-crisis (for normal baseline) and crisis-hit enterprises. In addition, we adopted a ridge regression to produce coefficients that predict and extrapolate better than least squares and offer a safe procedure for selecting variables when independent variables are highly correlated $[28,44]$. The 15 financial variables and 9 corporate governance variables for China and 15 financial variables and 13 corporate governance variables for Taiwan were leftover after the Wilcoxon test and ridge regression.

Table 1. Failure vs. non-failure samples for China

\begin{tabular}{cccccccc}
\hline $\begin{array}{c}\text { Event } \\
\text { Year }\end{array}$ & $\begin{array}{c}\text { Restructure/Ove } \\
\text { rdue }\end{array}$ & $\begin{array}{c}\text { CPA } \\
\text { opinoin }\end{array}$ & $\begin{array}{c}\text { Negative net } \\
\text { asset value }\end{array}$ & Tunneling & Close & Default & Normal \\
\hline 2006 & $16(0.99)$ & $79(4.89)$ & $41(2.54)$ & $5(0.31)$ & $12(0.74)$ & $153(9.48)$ & 1308 \\
2007 & $22(1.37)$ & $69(4.29)$ & $43(2.67)$ & $2(0.12)$ & $7(0.44)$ & $143(8.89)$ & 1322 \\
2008 & $11(0.74)$ & $84(5.68)$ & $30(2.03)$ & $0(0.00)$ & $3(0.20)$ & $128(8.65)$ & 1224 \\
2009 & $13(0.85)$ & $107(6.96)$ & $20(1.30)$ & $0(0.00)$ & $5(0.33)$ & $145(9.43)$ & 1248 \\
2010 & $7(0.34)$ & $85(4.17)$ & $26(1.28)$ & $1(0.05)$ & $4(0.20)$ & $123(6.04)$ & 1790 \\
Total & $69(0.83)$ & $424(5.12)$ & $160(1.93)$ & $8(0.10)$ & $31(0.37)$ & $692(8.36)$ & 6892 \\
\hline
\end{tabular}

The percentage of events was shown in parenthese

Table 2. Failure vs. non-failure samples for Taiwan

\begin{tabular}{cccccccc}
\hline $\begin{array}{c}\text { Event } \\
\text { Year }\end{array}$ & $\begin{array}{c}\text { Bounce/ } \\
\text { Overdue/ } \\
\text { Bailout }\end{array}$ & $\begin{array}{c}\text { CPA } \\
\text { opinoin }\end{array}$ & $\begin{array}{c}\text { Restructure/ } \\
\text { Bankruptcy }\end{array}$ & Tunneling & $\begin{array}{c}\text { Close/ } \\
\text { Full-cash } \\
\text { delivery }\end{array}$ & default & Normal \\
\hline 2006 & $28(5.13)$ & $10(1.83)$ & $8(1.47)$ & $8(1.47)$ & $3(0.55)$ & $57(10.4)$ & 432 \\
2007 & $25(3.68)$ & $14(2.06)$ & $6(0.88)$ & $6(0.88)$ & $7(1.03)$ & $58(8.53)$ & 564 \\
2008 & $24(3.46)$ & $10(1.44)$ & $8(1.15)$ & $10(1.44)$ & $2(0.29)$ & $54(7.79)$ & 585 \\
2009 & $25(3.73)$ & $5(0.75)$ & $8(1.19)$ & $10(1.49)$ & $5(0.75)$ & $53(7.91)$ & 564 \\
2010 & $10(1.72)$ & $5(0.86)$ & $5(0.86)$ & $4(0.69)$ & $2(0.34)$ & $26(4.47)$ & 530 \\
Total & $112(1.35)$ & $44(0.53)$ & $35(0.42)$ & $38(0.46)$ & $19(0.23)$ & $248(3.00)$ & 2675 \\
\hline
\end{tabular}

The percentage of events was shown in parenthese. 


\section{Results and Analysis}

Financial variables/ratios and corporate governance variables were selected by the independent-sample $t$-test between each factor as an input variable, and bankruptcy or non-bankruptcy was used as the output variable. We then adopted a logistic regression stepwise to filter the major factors of bankruptcy prediction.

\subsection{China's Models}

Table 3 presents the result of considering financial, corporate governance, and integrated variables for China's models, respectively. Model 1 considers six significant financial indicators of bankruptcy through the stepwise regression. Over the sample period, Operating profit margin and Acid-test ratio (ACID) were negatively associated with the likelihood of bankruptcy. These results strengthen the hypothesis that those companies with higher profit and debt-paying ability would have reduced the risk of collapse. Two consecutive years of losses for enterprises is also an important signal of imminent bankruptcy in China. Alternatively, total assets turnover and total assets exhibit a negative association with the probability of bankruptcy. Larger firms appear to have greater ease in maintaining ongoing operations during financial crisis periods.

Model 3 shows that the relation between corporate governance variables (shares-holding of non-outstanding domestic institutions and shares-holding of non-outstanding placement institutions) and prediction failure are positive. These results partly support the conclusions of Ching, Firth, and Rui [14]. In China, foreign supervision and small shareholder protection systems are much weaker, public shareholders cannot be sufficiently shielded from the positive relation between the ratio of corporate-held shares and financial crisis. The variable, shares-holding of non-outstanding state shares, in China also has a significant impact on default prediction, which is consistent with our expected results. An increase in the variable shares-holding of non-outstanding foreign institutions shifts enterprises towards a lower probability of bankruptcy. Foreign institutions, generally speaking, are able to exert an external oversight function, so that higher share-holding causes a downturn of enterprise bankruptcies. A higher TOP 10 corresponds to a lower insolvency risk. On average, holding a higher proportion of TOP 10 (shares held by top 10 main shareholders) is associated with better operational performance, because they will have great supervisory aspirations and the agency problem will be reduced. Finally, board pledge rate and ratio of bonus of directors and supervisors were also positively and significantly associated with financial distress.

As can be seen from model 5 in Table 3, shares-holding of non-outstanding domestic institutions and TOP 10 are not significantly associated with enterprise crises, compared with model 1. Other estimated variables have the same expectation as in model 5 .

Table 3. Pre-warning models of China

\begin{tabular}{|c|c|c|c|c|}
\hline Variabes & Expected signal & Model 1 & Model 3 & Model 5 \\
\hline Intercept & & $\begin{array}{c}-3.644^{* * *} \\
(0.202)\end{array}$ & $\begin{array}{c}-2.467^{* * *} \\
(0.154)\end{array}$ & $\begin{array}{c}0.184 \\
(0.826)\end{array}$ \\
\hline Operating profit margin $(\%)$ & - & $\begin{array}{c}-0.061^{* * *} \\
(0.006)\end{array}$ & $\mathrm{N}$ & $\begin{array}{c}-0.453^{* * *} \\
(0.006)\end{array}$ \\
\hline ACID (\%) & - & $\begin{array}{c}-0.007^{* * *} \\
(0.002)\end{array}$ & $\mathrm{N}$ & $\begin{array}{c}-0.009^{* * *} \\
(0.002)\end{array}$ \\
\hline Debit ratio $(\%)$ & + & $\begin{array}{l}0.014^{* * *} \\
(0.002)\end{array}$ & $\mathrm{N}$ & $\begin{array}{l}0.012^{* * *} \\
(0.002)\end{array}$ \\
\hline Two consecutive years of losses & + & $\begin{array}{l}2.094^{* * *} \\
(0.137)\end{array}$ & $\mathrm{N}$ & $\begin{array}{l}2.088^{* * *} \\
(0.143)\end{array}$ \\
\hline Days payables outstanding (days) & - & $\begin{array}{l}0.007^{* * *} \\
(0.002)\end{array}$ & $\mathrm{N}$ & $\begin{array}{l}0.005^{* * *} \\
(0.001)\end{array}$ \\
\hline Total assets turnover (times) & - & $\begin{array}{c}-0.596^{* * *} \\
(0.047)\end{array}$ & $\mathrm{N}$ & $\begin{array}{c}-0.357^{* * *} \\
(0.147)\end{array}$ \\
\hline Total assets $(\ln )$ & - & $\mathrm{N}$ & $\mathrm{N}$ & $\begin{array}{l}0.005^{* * *} \\
(0.001)\end{array}$ \\
\hline Shares-holding of non-outstanding state shares $(\%)$ & + & $\mathrm{N}$ & $\mathrm{N}$ & $\begin{array}{c}-0.357^{* * *} \\
(0.147)\end{array}$ \\
\hline $\begin{array}{l}\text { Shares-holding of non-outstanding domestic institutions } \\
(\%)\end{array}$ & + & $\mathrm{N}$ & $\begin{array}{l}0.016^{* * *} \\
(0.002)\end{array}$ & $\mathrm{N}$ \\
\hline $\begin{array}{l}\text { Shares-holding of non-outstanding placement institutions } \\
\qquad(\%)\end{array}$ & + & $\mathrm{N}$ & $\begin{array}{l}0.092^{* * *} \\
(0.006)\end{array}$ & $\begin{array}{l}0.035^{* * *} \\
(0.009)\end{array}$ \\
\hline Shares-holding of non-outstanding foreign institutions (\%) & - & $\mathrm{N}$ & $\begin{array}{l}-0.036^{* * *} \\
(0.016)\end{array}$ & $\begin{array}{c}-0.137^{* * *} \\
(0.04)\end{array}$ \\
\hline TOP $10(\%)$ & - & $\mathrm{N}$ & $\begin{array}{l}-0.027^{* * *} \\
(0.003)\end{array}$ & $\mathrm{N}$ \\
\hline Board pledge rate $(\%)$ & + & $\mathrm{N}$ & $\begin{array}{l}0.032^{* * *} \\
(0.003)\end{array}$ & $\begin{array}{l}0.020^{* * *} \\
(0.003)\end{array}$ \\
\hline Ratio of bonus of directors and supervisors (\%) & + & $\mathrm{N}$ & $\begin{array}{l}0.021^{* * *} \\
(0.003)\end{array}$ & $\begin{array}{l}0.023^{* * *} \\
(0.003)\end{array}$ \\
\hline
\end{tabular}

Note: $\mathrm{ACID}=$ Acid-test ratio $(\%)$; TOP $10=$ Shares held by top 10 main shareholders $(\%) ;^{* * *}$ Denotes significance at $1 \%$. 


\subsection{Taiwan's Models}

The results of Taiwan's pre-warning models are summarized in Table 4, where the logistic regression model identifies four financial variables as predictors of financial distress in model 2 through a stepwise selection process. In model 2, the profitability (ROA, Gross profit margin) indicated that a business producing greater benefits corresponds to a lower likelihood of bankruptcy. Interest-bearing debt/shareholders' equity was positive and significantly related to financial distress because as loan dependence increases, a higher interest-bearing debt and a lower debt capacity increase a firm's financial instability.

Model 4 of Table 4 reports the estimates of the pre-warning model that only considers corporate governance in Taiwan. Shares held by directors and supervisors and deviation between cashflow and voting were confirmed as negative and significant predictors of financial distress. The result of the positive relation between bankruptcy probability and board pledge rate is also reported in model 4 , in line with our anticipations. Higher board pledge rate levels indicate a company in crisis. Double leverage ratio was positively associated with bankruptcy likelihood. A strategy of diversification will reduce enterprise risk but investment failure leads to a more serious crisis. Financial statement restated and turnover of decision-makers have a positive impact upon bankruptcy prediction. These results demonstrate that financial statement with lower reliability and a higher turnover of decision-makers correspond to a higher probability of failure.

Model 6 of Table 4 reports the results from incorporating simultaneous financial data and corporate governance variables in Taiwan's prediction model. The cross-shareholding has a positive effect on a firm's failure. It occurs much more often in Taiwan, and when it does appear, it is intended to achieve specific objectives; hence, it hurts a firm's profit margins. Days payables outstanding and days receivables outstanding exhibited a significant positive and negative association with the bankruptcy prediction, respectively. Perhaps if days payables outstanding is very long, the firm would lose a cash discount, thus causing revenues to fall and the crisis to intensify. When there is a longer day receivables outstanding to a counterpart whose cash discount would be canceled, then a firm has a higher income and a lower risk.

Table 4. Pre-warning models of Taiwan

\begin{tabular}{|c|c|c|c|c|}
\hline Variabes & Expected signal & Model 2 & Model 4 & Model 6 \\
\hline Intercept & & $\begin{array}{c}-3.534^{* * *} \\
(0.351)\end{array}$ & $\begin{array}{c}-2.512^{* * *} \\
(0.339)\end{array}$ & $\begin{array}{l}-0.064 \\
(2.084)\end{array}$ \\
\hline ROA (\%) & - & $\begin{array}{c}-0.481^{* * *} \\
(0.055)\end{array}$ & $\mathrm{N}$ & $\begin{array}{c}-0.197^{* * *} \\
(0.060)\end{array}$ \\
\hline Gross profit margin $(\%)$ & - & $\begin{array}{c}-0.049^{* * * *} \\
(0.013)\end{array}$ & $\mathrm{N}$ & $\begin{array}{c}-0.056^{* * *} \\
(0.019)\end{array}$ \\
\hline Net profit margin $(\%)$ & - & $\mathrm{N}$ & $\mathrm{N}$ & $\begin{array}{c}-0.198^{* * *} \\
(0.043)\end{array}$ \\
\hline Interest-bearing debt/shareholders' equity (\%) & + & $\begin{array}{c}0.010^{* * *} \\
(0.001)\end{array}$ & $\mathrm{N}$ & $\begin{array}{l}0.008^{* * *} \\
(0.001)\end{array}$ \\
\hline Days payables outstanding (days) & - & $\begin{array}{l}0.023^{* * *} \\
(0.003)\end{array}$ & $\mathrm{N}$ & $\begin{array}{l}0.035^{* * *} \\
(0.006)\end{array}$ \\
\hline Days receivables outstanding (days) & + & $\mathrm{N}$ & $\mathrm{N}$ & $\begin{array}{c}-0.012^{* * *} \\
(0.005)\end{array}$ \\
\hline Total assets $(\ln )$ & - & $\mathrm{N}$ & $\mathrm{N}$ & $\begin{array}{c}-0.243^{* * *} \\
(4.031)\end{array}$ \\
\hline Shares held by directors and supervisors (\%) & - & $\mathrm{N}$ & $\begin{array}{l}-0.032 \\
(0.008)\end{array}$ & $\begin{array}{c}-0.346^{* * *} \\
(0.011)\end{array}$ \\
\hline Cross-shareholding $(\%)$ & + & $\mathrm{N}$ & $\mathrm{N}$ & $\begin{array}{l}1.185^{* * *} \\
(0.325)\end{array}$ \\
\hline Board pledge rate (\%) & + & $\mathrm{N}$ & $\begin{array}{c}0.010^{* * *} \\
(0.004)\end{array}$ & $\mathrm{N}$ \\
\hline Deviation between cashflow and voting & - & $\mathrm{N}$ & $\begin{array}{c}-0.010^{* * *} \\
(0.003)\end{array}$ & $\mathrm{N}$ \\
\hline Ratio of bonus of directors and supervisors (\%) & + & $\mathrm{N}$ & $\begin{array}{c}-1.514^{* * *} \\
(0.209)\end{array}$ & $\begin{array}{c}-0.886^{* * *} \\
(0.262)\end{array}$ \\
\hline Double leverage ratio (\%) & + & $\mathrm{N}$ & $\begin{array}{c}0.004^{* * *} \\
(0.001)\end{array}$ & $\mathrm{N}$ \\
\hline Financial statement restated (times) & + & $\mathrm{N}$ & $\begin{array}{c}0.333^{* * *} \\
(0.074)\end{array}$ & $\begin{array}{c}0.313^{* * *} \\
(0.116)\end{array}$ \\
\hline Turnover of decision-makers (times) & + & $\mathrm{N}$ & $\begin{array}{c}0.398^{* * *} \\
(0.037)\end{array}$ & $\begin{array}{c}0.357^{* * *} \\
(0.046)\end{array}$ \\
\hline
\end{tabular}

Note: $\mathrm{ROA}=$ Return on assets; ${ }^{* * *}$ Denotes significance at $1 \%$. 
Table 5. Goodness of fit measures

\begin{tabular}{ccccccccc}
\hline & \multirow{2}{*}{$\begin{array}{c}\text { Model } \\
\text { Method }\end{array}$} & \multicolumn{2}{c}{ Financial data } & \multicolumn{2}{c}{ Corporate governance } & \multicolumn{2}{c}{ Integrated model } \\
\cline { 2 - 8 } & Training & Testing & Training & Testing & Training & Testing \\
\hline \multirow{3}{*}{ China } & ROC (\%) & 87.64 & 86.66 & 75.99 & 75.32 & 89.38 & 87.13 \\
& KS (\%) & 63.77 & 62.42 & 41.22 & 39.46 & 66.30 & 63.50 \\
\multirow{3}{*}{ Taiwan } & ROC (\%) & 89.98 & 83.22 & 86.41 & 84.05 & 92.98 & 84.93 \\
& KS (\%) & 66.78 & 51.49 & 62.55 & 60.19 & 73.78 & 64.59 \\
\hline
\end{tabular}

\subsection{Models Comparison}

Comparing the estimates in Table 3 and 4, China's financial data focuses on profitability, debt-paying ability, and operating capacity through three stages, but the main Taiwanese data fall into the first two categories. For controlling interest and director structure in Taiwan, a negative and significant relation associated with shares held by directors and supervisors and financial crisis was found, which is in accordance with the "convergence of interest hypothesis," which states that a higher ratio of share-holding leads to better management and supervision, as provided by Jensen and Meckling [30], but which is not largely applicable in China. Board pledge rate and financial crisis have a positive relation in both China and Taiwan. Note that the signs of ratio of bonus of directors and supervisors differ between China and Taiwan. The negative and significant coefficients for the ratio of bonus of directors and supervisors in models 2 and 4 can perhaps be explained by different levels of family businesses. If enterprises perform better, then the board of directors will receive higher bonuses, a prospect which shows a positive relation with firm value. For China, directors and supervisors were state or corporate shareholders, the former who received them as a political reward, and the latter owning non-outstanding shares, so those do not reflect firm performance.

In terms of financial transparency, financial statement restated and turnover of decision-makers are positively related with financial crisis in Taiwan, but financial statements by a Big 4 audit is not significant in China. This finding can perhaps be illustrated by the lower market share of Big 4 audit firms in China, so it cannot distinguish between normal and abnormal. Both shares-holding of non-outstanding state shares and shares-holding of non-outstanding placement institutions are positive and significant in the pre-warning model, a finding in accordance with the "conflicts of interest hypothesis" in which stock-holder rights centralizing with a few directors mean that their successful predatory behavior will result in poor firm performance. Shares-holding of non-outstanding foreign institutions negatively impacts financial crises, as they have the primary aim of earning capital gains and ensuring effective supervision in accordance with the "efficient supervisions hypothesis." However, following Chen et al. (2006), we used comprehensive development index (CDI) from China's national social statistics as a proxy variable for regional development in model 5 , but it does appear insignificant.

\subsection{Predictive Power}

A comparative assessment of the prediction power of the logit model and associated ROC and KS values are presented in Table 5. Clearly, Table 5 shows that the integrated model has the highest ROC and KS values among models, and therefore, it has the best capacity to discriminate pre-warning models. Taiwan's model, moreover, is slightly superior to China's model within the models of estimation. Comparing the training set with the testing set demonstrates that the value of ROC and KS only slightly decreased in the testing set and that the proposed model was stable and effective in finding the optimal bankruptcy prediction.

\section{Conclusions}

In this paper, we investigate a pre-warning model of cross-strait listed companies, and employed financial and corporate governance variables in a logit model. Traditional financial variables form the basis of predicting bankruptcy, while corporate governance variables provide much more forward-looking information about a company's future prospects. We find that both shares-holding of non-outstanding state shares and shares-holding of non-outstanding placement institutions are positive and significant predictors in China, a finding that upholds the "conflicts of interest hypothesis." Shares-holding of non-outstanding foreign institutions negatively impacts financial crises, a finding that is in keeping with the "efficient supervisions hypothesis." The negative coefficient of shares held by directors and supervisors is as expected in Taiwan, in accordance with the "convergence of interest hypothesis." The positive relation between cross-shareholding and firm failure is a special case in Taiwan. The predictive power of the integrated models substantially improves when financial and corporate governance data are combined. Taiwan's model is slightly superior to China's model within the models of the estimation. The results clearly demonstrate that the proposed model was solid and effective in finding the optimal bankruptcy prediction. Most importantly, the findings present an adequate bankruptcy prediction model 
of cross-strait companies and can better help corporations to face a financial crisis and the challenges met with in competitive global markets.

There is a limitation to this paper. Uncertainty in the economic environment seems to multiply the detrimental pressures facing a business, wherefore the authorities should apply macroeconomic and industry development to identify other possible factors; moreover, crisis events and enterprise fraud also maybe important influential factors. Although this paper establishes an integrated model to improve the effectiveness of the early warnings of financial distress, some issues may be worth investigating in future research studies. The Merton distance to default could be merged into a logit model, which could then possibly provide a more consolidated pre-warning model.

\section{Appendix A}

Table A1. Corporate governance variables for China

\begin{tabular}{|c|c|c|}
\hline Dimension & Variable & Description \\
\hline \multirow{9}{*}{$\begin{array}{c}\text { Ownership structure and } \\
\text { shares-holding by directors and } \\
\text { supervisors }\end{array}$} & Non-outstanding state shares (\%) & State shares/total capital \\
\hline & Non-outstanding domestic institutions (\%) & Domestic institutions shares-holding/total capital \\
\hline & Non-outstanding placement institutions (\%) & Placement institutions shares-holding/outstanding shares \\
\hline & Non-outstanding foreign institutions (\%) & Foreign institutions shares-holding/outstanding shares \\
\hline & Restrict action shares (\%) & Restrict action shares / total capital \\
\hline & Top 10 main shareholders $(\%)$ & Shares held by top 10 main shareholders/total capital \\
\hline & Board pledged ratio & $\begin{array}{c}\text { Shares delivered(pledge)/shares held by directors and } \\
\text { supervisors }\end{array}$ \\
\hline & Ratio of shares held by directors and supervisors & $\begin{array}{l}\text { Shares held by directors and supervisors/outstanding } \\
\text { shares }\end{array}$ \\
\hline & Restrict circular shares & $\begin{array}{l}\text { Shares held by directors and supervisors/restrict action } \\
\text { shares }\end{array}$ \\
\hline $\begin{array}{l}\text { Equitable treatment of } \\
\text { shareholders }\end{array}$ & Ratio of bonus of directors and supervisors & Bonus of directors and supervisors/net income \\
\hline Quality of financial reporting & Financial statements by Big 4 audit & $\begin{array}{l}\text { If financial statements by Big } 4 \text { audited, then the value is } \\
\text { " } 1 \text {," otherwise " } 0 . "\end{array}$ \\
\hline
\end{tabular}

Table A2. Corporate governance factors for Taiwan






\section{REFERENCES}

[1] Altman, E. I. (1968) Financial ratios, discriminant analysis and the prediction of corporate bankruptcy, The Journal of Finance, 23, 589-609.

[2] Altman, E. I. Haldeman, R. G. and Narayanan, P. (1977) ZETA $^{\mathrm{TM}}$ analysis a new model to identify bankruptcy risk of corporations, Journal of Banking \& Finance, 1, 29-54.

[3] Altman, E. I. (2014) Revisiting the recidivism - Chapter 22 phenomenon in bankruptcy system, Brooklyn Journal of Corporate, Financial \& Commercial Law, 8, 253-277.

[4] Bayrakdaroglu, A., Ersoy, E. and Citak, L. (2012) Is there a relationship between corporate governance and value-based financial performance measures? A study of Turkey as an emerging market, Asia-Pacific Journal of Financial Studies, 41, 224-239.

[5] Beaver, W. H., McNichols, M. and Rhie, J. W. (2005) Have financial statements become less informative? Evidence from the ability of financial ratios to predict bankruptcy, Review of Accounting Studies, 10, 93-122.

[6] Berkson, J. (1944) Application of the logistic function to bio-assay, Journal of the American Statistical Association, 39, 357-365.

[7] Blundell-Wignall, A. (2007) Structured products: Implications for financial markets, Financial Maket Trend, 2, $27-57$.

[8] Boritz, J. E., Kennedy, D. B. and Sun, J. Y. (2007) Predicting business failure in Canada, Accounting Perspectives, 6, 141-165.

[9] Brown, S., Dietrich, M. and Nuñez, A. O. (2013) Taylor, K. Business ownership and attitudes towards risk, Applied Economics, 45, 1731-1740.

[10] CFA. (2007) China corporate governance survey, CFA Institute.

[11] Chen, F. H., Chi, D. J. and Kuo, C. Y. (2014) Using rough set theory and decision trees to diagnose enterprise distress-consideration of corporate governance variables, Intelligent Computing Methodologies, 6, 18-33.

[12] Chen, G., Firth, M., Gao, D. N. and Rui, O. M. (2006) Ownership structure, corporate governance, and fraud: Evidence from China, Journal of Corporate Finance, 12, 424-448.

[13] Chen, Z., Wang, L. and Wang, K. (2011) Financial risk pre-warning model based on wavelet neural network date from the listed logistics companies in Chinese, International Journal of Advancements in Computing Technology, 3, 325332.

[14] Ching, K. M., Firth, L. M. and Rui, O. M. (2006) Earnings management, corporate governance and the market performance of seasoned equity offerings in Hong Kong, Journal of Contemporary Accounting \& Economics, 2, 7398 .

[15] Chiou, J. R., Hsiung, T. C. and Kao, L. (2002) A study on the relationship between financial distress and collateralized shares, Taiwan Accounting Review, 3, 79-111.

[16] Claesses, S., Djankor, S., Fan, J. P. and Lang, L. H. (2002) Disentangling the incentive and entrenchment effects of large shareholdings, The Journal of Finance, 57(6), 27412771.

[17] Daily, C. and Dalton, D. (1994) Bankruptcy and corporate governance: The impact of board composition and structure, Academy of Management, 37, 1603-1617.

[18] Duan, J. C., Sun, J. and Wang, T. (2012) Multiperiod corporate default prediction-A forward intensity approach, Journal of Econometrics, 170, 191-209.

[19] Duffie, D., Saita, L. and Wang, K. (2007) Multi-period corporate default prediction with stochastic covariates, Journal of Financial Economics, 83, 635-665.

[20] Erkens, D. H., Hung, M. and Matos, P. (2012) Corporate governance in the 2007-2008 financial crisis: Evidence from financial institutions worldwide, Journal of Corporate Finance, 18, 389-411.

[21] Frank, J. and Massey, Jr. (1951) The Kolmogorov-Smirnov test for goodness of fit, Journal of the American Statistical Association, 46, 68-78.

[22] Fuenzalida, D., Mongrut, S., Arteaga, J. R. and Erausquin, A. (2013) Good corporate governance: Does It pay in Peru? Journal of Business Research, 66, 1759-1770.

[23] Greiner, M. Pfeiffer, D. and Smith, R. D. (2000) Principles and practical application of the receiver-operating characteristic analysis for diagnostic tests, Preventive Veterinary Medicine, 45, 23-41.

[24] Hamdi, M. and Mestiri, S. (2014) Bankruptcy prediction for Tunisian firms: An application of semi-parametric logistic regression and neural networks approach, Economics Bulletin, 34, 133-143.

[25] Hand, D. J. and Anagnostopoulos, C. (2013) When is the area under the receiver operating characteristic curve an appropriate measure of classifier performance? Pattern Recognition Letters, 34, 492-495.

[26] Hanley, J. A. and McNeil, B. J. (1982) The meaning and use of the area under a receiver operating characteristic (ROC) Curve, Radiology, 143, 29-36.

[27] He, X., Wong, T. J. and Young, D. (2012) Challenges for implementation of fair value accounting in emerging markets: Evidence from China, Contemporary Accounting Research, 29, 538-562.

[28] Hofmarcher, P., Kerbl, S., Grün, B., Sigmund, M. and Hornik, K. (2014) Model uncertainty and aggregated default probabilities: New evidence from Austria, Applied Economics, 46, 871-879.

[29] Huang, D. T., Chang, B. and Liu, Z. H. (2012) Bank failure prediction models: for the developing and developed countries, Quality \& Quantity. 46, 553-558.

[30] Jensen, M. C. and Meckling, W. H. (1976) Theory of the firm: Managerial behavior, agency costs and ownership structure. Journal of Financial Economics, 3, 305-360.

[31] Joh, S. W. and Jung, Y. J. (2012) The effects of outside 
board on firm value in the emerging market from the perspective of information transaction Cost, Asia-Pacific Journal of Financial Studies, 41, 175-193.

[32] Kasgari, A. A., Divsalar, M. and Javid, M. R. and Ebrahimian, S. J. (2013) Prediction of bankruptcy Iranian corporation through artificial neural network and Probit-based analyses, Neural Computing and Application, 23, 927-936.

[33] Kleffner, A. E., Lee, R. B. and McGannon, B. (2003) The effect of corporate governance of the use of enterprise risk management: Evidence from Canada, Risk Management and Insurance Review, 6, 53-73.

[34] Lau, A. H. L. (1987) A five-state financial distress prediction model, Journal of Accounting Research, 25, 127-138.

[35] Liu, Q. (2006) Corporate governance in China: Current practices, economic effects and institutional determinants, CESifo Economic Studies, 52, 415-453.

[36] Mays, E. (2003) Credit Scoring For Risk Managers: The Handbook for Lenders. South-Western Educational Publish, 1 edition.

[37] Muller, G. H. Steyn-Bruwer, B. W. and Hamman, W. D. (2009) Predicting financial distress of companies listed on the JSE-A comparison of techniques, South African Journal of Business Management, 40, 21-32.

[38] Nikolaos, L. and Iordanis, E. (2010) Default prediction and bankruptcy hazard analysis into recurent neuro-genetic hybrid networks to AdaBoost M1 regression and logistic regression models in Finance, Latest Trends on Systems, 1, $35-41$.

[39] OECD. (2014) Brochure on corporate governance in Asia. http://www.oecd.org/corporate/ Acessed 10 July 2014.

[40] Ohlson, J. A. (1980) Financial ratios and probabilistic prediction of bankruptcy, Journal of Accounting Research, 18, 109-131.

[41] Patton, A. and Baker, J. C. (1987) Why won't directors rock the boat? Harvard Business Review, 65, 10-18.

[42] Poletti-Hughes, J. and Ozkan, A. (2014) Ultimate controllers, ownership and the probability of insolvency in financially distressed firms, Managerial and Decision Economics, 35, $36-50$.

[43] Rim, EI. K. and Roy, Al. B. (2014) Classifying Manufacturing Firms in Lebanon: An Application of Altman's Model, Procedia - Social and Behavioral Sciences, 109, 11-18.

[44] Robert, M. (2007) O'brien, R.M.: A caution regarding rules of thumb for variance inflation factors, Quality \& Quantity. 41, 673-690.
[45] Schermelleh-Engel, K. and Moosbrugger, H. (2003) Evaluating the fit of structural equation models: Tests of significance and descriptive goodness-of-fit Memasures, Methods of Psychological Research, 8, 23-74.

[46] Selkälä, A., Ronkainen, S. and Alasaarela, E. (2011) Features of the Z-scoring method in graphical two-dimensional web surveys: the case of ZEF, Quality \& Quantity, 45, 609-621.

[47] Sharma, N., Arun, N. and Ravi, V. (2013) An ant colony optimisation and Nelder-Mead simplex hybrid algorithm for training neural networks: An application to bankruptcy prediction in banks, International Journal of Information and Decision Sciences, 5, 188-203.

[48] Shumway, T. (2001) Forecasting bankruptcy more accurately: A simple hazard model. The Journal of Business, 74, 101-124.

[49] Tasdan F. and Yeniay, O. (2014) A shift parameter estimation based on smoothed Kolmogorov-Smirnov, Journal of Applied Statistics, 41, 1147-1159.

[50] Trabelsi, S., He, R., He, L. and Kusy, M. (2014) A comparison of bayesian, hazard, and mixed logit model of bankruptcy prediction, Computational Management Science. doi:10.1007/s10287-013-0200-8.

[51] Tseng, F. M. and Hu, Y. C. (2010) Comparing four bankruptcy prediction models: Logit, quadratic interval logit, neural and fuzzy neural networks, Expert Systems with Applications, 37, 1846-1853.

[52] TWSE. (2014) Corporate governance evaluation system introduction.

http://www.twse.com.tw/en/listed/governance/cg_01.php. Accessed 15 July 2014.

[53] Uğurlu, M. and Aksoy, H. (2006) Prediction of corporate financial distress in an emerging market: the case of Turkey, Cross Cultural Management: An International Journal, 13, 277-295.

[54] Wintoki, M. B., Linck, J. S. and Netter, J. M. (2012) Endogeneity and the dynamics of internal corporate governance, Journal of Financial Economics, 105, 581-606.

[55] Yi, W. (2012) Z-score model on financial crisis early-warning of listed real estate Companies in China: A financial engineering perspective. Systems Engineering Procedia, 3, 153-157.

[56] Zmijewski, M. E. (1984) Methodological issues related to the estimation of financial distress prediction models, Journal of Accounting Research, 22, 59-82.

[57] Zweig M. H. and Campbell, G. (1993) Receiver-operating characteristic (ROC) plots: a fundamental evaluation tool in clinical medicine, Clinical Chemistry, 39, 561-577. 